\title{
History of Banking in Sudan (Conventional and Islamic): A Critical Review (1903-2019)
}

\author{
Omer Allagabo Omer Mustafa (Corresponding author) \\ Assistant Professor of Economics, Banking and Finance \\ Sudan Academy for Banking and Financial Sciences (SABFS-Sudan) \\ P.O. Box 1880 Khartoum-Sudan \\ E-mail: omergabo78@sabfs.edu.sd
}

Received: May 2, $2021 \quad$ Accepted: June 3, $2021 \quad$ Published: June 10, 2021

doi:10.5296/ifb.v8i1.18740 URL: http://dx.doi.org/10.5296/ifb.v8i1.18740

\begin{abstract}
This paper critically reviews the developmental stages of banking (Conventional and Islamic) in Sudan throughout the last 115 years (1903-2019). Historical and descriptive-analytical approaches were used. Historical data collected from the annual reports of The Central Bank of Sudan and relevant studies were used to describe and compare stages during that period. The results indicated that political instability and ideology changes of the state (e.g., Colonialism, independence and democracy, socialism and Islamic) systems played a significant role in the formation of stages of development of Sudan's banking systems (e.g., conventional, Islamic, dual system). Moreover, the implementation of the Islamic Sharia Law in 1983 was the original basis for the augmentation of the Islamization of the country's banking system, particularly as it pertained to the prohibition of charging interest. Under the Comprehensive Peace Agreement (CPA: 2005-2010), the conventional banking (interest rate) in Southern Sudan was restored, whereas the Islamic approach continued in the north. Notwithstanding, all banks were managed by one central bank in the north namely The Central Bank of Sudan. The study highlights the relationship between factors affecting political stability and the growth of stability and the banking system.
\end{abstract}

Keywords: history, banking, conventional, Islamic, Sudan, review 


\section{Introduction}

The banking system plays a major role in the mobilization and allocation of financial resources by serving as an intermediary between depositors/savers and customers/users of resources. Therefore, the banking system should exercise appropriate judgment regarding the viability of ventures and hence the borrower's ability to repay.

The Islamic banking system is based upon Islamic jurisprudence known as fiqh al-mu'amalat. The system considers the concept of social equity to be based on fairness in all business transactions, and it emphasizes the transparency of contractual obligations according to the divine law of Allah (Quran). It is based on Shariah-approved products which do not involve riba (interest/usury), gharar (uncertainty), maisir (gambling), and non-halal (prohibited) activities.

The roots of the present Islamic banking model can be traced back to the creation date of Islam in the 7th century and the emergence of the last messenger Mohammad (peace be upon him). The first Islamic bank was created in 1963 in Egypt.

This paper aims to trace the development of banking in Sudan over approximately the last one hundred years (1903-2019).

\subsection{Problem Statement}

The banking system in Sudan has witnessed many ups and downs over the years since its introduction in the early years of the 20th Century. The study tries to trace these developments to identify any trends or shared characteristics in so far required success factors are concerned. The idea on which the research is based is that the current development of the banking system is a product of past events that shaped the system and its activities. Thus, the development of the banking system has come through many stages during the last years. Each stage will be critically reviewed to clarify the most important characteristics during this period.

\subsection{Importance of the Research}

Although many studies were carried out globally in the area of the history of banking, there are few documentation studies relating to history of banking in Sudan. This paper seeks to contribute by highlighting the critical historical aspects of the banking system in Sudan during the period 1903-2019.

\subsection{Objectives of the Research}

The objectives of the research are:

- To critically review and discuss the roots of banking in Sudan during (1903-2019).

- To clarify the role of the Central Bank of Sudan in terms of reconstruction, reform, development, and the deepening of Islamization of the Banking System, especially after the secession of South Sudan on July 1st, 2011. 


\subsection{The Research Hypotheses}

The following hypotheses will be examined:

- Political factors played a vital role in the establishment and formation of the banking system in Sudan.

- Did Sudan consider the case of one of the early Islamic Countries that implemented the Principles of Islamic Shari'a in the formation of its banking system?

\subsection{Methodology and Data}

To investigate the hypotheses, both historical and descriptive-analytical approaches were used. Data were collected from annual reports of the Central Bank of Sudan (CBOS) and previous studies related to the issue of the paper.

\subsection{Literature Review}

Mohamed (1990) discussed the experience of the Sudanese Islamic Bank (SIB) in the implementation of Islamic banking procedures in the rural sector. The study found, on a smaller scale. that social justice advocated by Islamic ideology can be accomplished through Islamizing banking within the limited scope and competence of such institutions as SIB in the general economic order.

Magda (2005) reviewed the emergence of the Islamic banking system in Sudan within the last three decades. The study found that the system succeeded in immunizing dealings with riba (interest) through resorting to murabahah, mudarabah, musharaka, etc.

Abrahim and Abdelgadir (2011) investigated the efficiency performance of Islamic banks in Sudan. The results indicate that among twelve banks included in our sample, only two banks (one is the largest bank in the group and government-owned, and the second is a middle-sized, private bank), score technical efficiency level (i.e., scale and pure technical efficiency). The smallest bank in the group (the privately-owned) scores on pure technical efficiency (i.e., managerial efficiency) but on the scale it is inefficient. These results imply that ownership is not a constraint on managerial and scale efficiency but a bank's size is an important factor for scale efficiency.

Shahid (2011) evaluated the current economic environment and activities of Islamic banks in Sudan. The study found that there is a need to integrate efforts between economists and scholars of Shari'ah (Islamic law) to create an Islamic intermediation system to redeem centuries of underdevelopment of the Muslim world.

Mohammad et al. (2013) reviewed the historical development of modern Islamic banking in selected Southeast Asian countries. The results show that the Islamic banking industry has developed and evolved in several South-East Asia countries including Brunei, the Philippines, Indonesia, Malaysia, Singapore and Thailand. Besides that, in South-East Asian countries, there are some informal arrangements for mobilizing financial resources.

Alharbi (2015) provided information about the historical development of the Islamic banking 
industry in many countries around the world. The study found that the Islamic financial industry is booming worldwide, though regulators must react to this by issuing laws to govern Islamic financial institutions' operations.

Mumtaz et al. (2015) discussed the expansion of Islamic finance. The study found that Islamic finance has expanded rapidly and is spreading across many regions. Islamic financial assets grew, on average, about 20 percent annually over the past decade. Despite this growth, Islamic finance still represents a very small share of global financial assets. To this end, several factors still constrain the realization of the full potential of Islamic finance.

Although many research papers have discussed the roots of banking historically, this paper seeks to review the history of banking (Conventional and Islamic) in Sudan during the period 1903-2019.

\section{Establishment of Commercial Banks in Sudan (1903-1955)}

The establishment of commercial banks in Sudan did not coincide with the beginning of banks in the world in the 17th century. The growth of the financial intermediaries in Sudan, as in many other Developing Countries, was greatly affected by the political and economic situations prevalent in Africa during the colonial era. Politically, Sudan was under joint British and Egyptian influence from 1898-1955, and its economic features were linked to the colonies' objectives and attitudes.

The history of conventional commercial banks in Sudan started with the beginning of the English-Egyptian Rule. When the bilateral agreement between Britain and Egypt was a signed; some modern systems were introduced to Sudan in the area of security, administration, judiciary, health, education, transport, and agriculture. These modern systems created a climate for economic development. Therefore, new markets for cash crops emerged and rulers began to search for commercial banks to meet the needs of the country's development at the time.

The establishment of the National Bank of Egypt in 1898, which was permitted to provide financial services in both Egypt and Sudan, planned to open the first branch in Sudan in 1903.

Thereafter Barclays' Bank was authorized to operate in Sudan in 1913, followed by the Turkish Ottoman Bank in 1946 (Omer, 1992, p. 52).

Banking businesses in Sudan coincided with the opening of the branch of National Bank of Egypt in 1903 (Al-Shosh, 1977, p. 9).

There was a group of foreign banks that have thirty-seven branches spread across the different regions of Sudan were controlled the banking arena (CBOS, 10th Annual Report, 1969, p. 90). Bank of Egypt was inaugurated in 1953. The French branch of Credit Lyonnais was opened in Khartoum in 1953 (CBOS, 5th Annual Report, 1964, p. 58).

Before independence of Sudan there was an absence of a central bank and beside national banks, the functions of the Central Bank were entrusted to the Ministry of Finance and Economy and to the National Bank of Egypt. 
Before independence of Sudan, some of the functions of the Central Bank of Sudan (CBOS) were divided between the Ministry of Finance, Sudan Currency Board and the National Bank of Egypt. The Ministry of Finance maintained part of the official foreign exchange balances through two accounts, one in USD and the other in Pounds Sterling which were managed respectively by the National Bank of Egypt and Barclays Bank D.C.O. As to the currency Board, it used to perform the task of issuing and managing the currency and to keeping a part of the country's balance in foreign currency as a cover for the national currency.

Also, the branch of the National Bank of Egypt used to manage the banking activities of the government besides discharging its main role as the bank of commercial banks (bank of the banks) at the same time. During this period, the Egyptian and British currencies were prevailing until the first national currency was issued (CBOS, 2019).

\section{Beyond Sudan's Independence: The Establishment of Bank of Sudan (1956-1960)}

After Sudan's independence on January 1st, 1956, there was a need for a Central Bank to replace the existing bodies and to perform its functions of regulating the process of the issuance of the national currency, formulating and directing monetary and financing policies to serve various economic sectors, building up a strong, efficient and effective banking system that meets the development needs of the country, maintaining government accounts, acting as an adviser for the government on financial affairs and providing foreign currency for the development projects adopted by the government at that time. To achieve the above-mentioned objectives, a committee of three (Note 1) experts from the United States Federal Reserve was formed in December 1956. It was worked with Sudan's government and finance specialists to create the Bank of Sudan Act (CBOS, 2019).

Thereafter, in 1956, the branch of the Arab-Jordan Bank established its activities in Sudan and this was followed by a branch of the Ethiopian Commercial Bank immediately after independence. Also Commercial Bank of Sudan was established in 1957 and is considered the first national commercial bank (Al-Khalil, 1999, p. 448) followed by the approval of the Act of Specialized Banks.

In March 1957, the Committee was requested to conduct a study on the possibilities of establishing a Central Bank in Sudan. The national authorities sought to find a Sudanese identity especially in the banking field; therefore, Sudan Currency Board (SCB) was established in 1958 to issue the first national currency. And it was granted the powers of issuing the local notes and coins to replace the foreign currencies which were in circulation (Bank of Sudan Act, 1959, p. 5).

This was followed by the issuance of the Bank of Sudan Act of 1959. The Act stipulated that the Bank of Sudan shall have an independent corporate personality, legal personality and a perpetual succession and a common seal and may litigate in its own name as a plaintiff defendant (CBOS, 2019).

To establish the Bank of Sudan, the Sudanese government nationalized the National Bank of Egypt's operations in the Sudan (some seven branches) and combined them with the Sudanese Currency Board. Following that, Sudanese officials were appointed to replace Egyptian 
officials, while the junior staff that used to work for the National Bank of Egypt were retained (Bank of Sudan, 2019).

In March 1959, the Agricultural Bank of Sudan was established with capital which amounted to 6.1 million Sudanese pounds in order to grant loans to small and medium cultivators as well as cooperatives (Ibid, p. 6).

On Feb 22, 1960, the Bank of Sudan was established and began its activities as the Central Bank. Its main branch opened in the capital Khartoum as well as three branches in the cities of Wad-Medani, Port-Sudan and Al-Ubayyid. The first Governor of Bank of Sudan was his Excellency / Mamoun Behairy (Bank of Sudan Act, 1959, p. 5).

In response to expansion in trade and commerce, the Sudanese Commercial Bank was established on 5th November 1960. Hence the first history decade of the Sudanese banking system was concluded in issuing a special law, establishing the Bank of Sudan and to allow it to operate as a central bank in 1959. The principal objectives of the Bank of Sudan are: To regulate the issuance of local currency, credit, supervise the banking system, be responsible for granting licenses to commercial and specialized banks and to enact both monetary and credit policy (Bank of Sudan, 11th Annual Report, 1970, pp. 106-107).

\section{Reform of Banking System in Sudan (1961-1994)}

The period 1961-1994 reviews the development of the banking system in Sudan by dividing it into five phases: The first phase represents the post-establishment period of the Bank of Sudan up to the nationalization of foreign banks (1961-1970), the second phase represents the period after nationalization, named The Open Door Policy (ODP), up to the emergence of Islamic banks (1971-1977), the third phase represents the dual banking system or Islamic and traditional combined (1978-1982), the fourth phase

considers the first stage of Islamization of the banking system (1983-1989) and the fifth phase represents the deepening of Islamization of the banking system until the announcement of primary procedures of the Reconstruction Program and the Reform of the Banking System (RPRBS) during (1990-1994).

\subsection{The First Phase (1961-1970)}

On the $17^{\text {th }}$ November 1961, the government of Sudan established the Industrial Bank of Sudan and charged it with responsibility for providing financial and technical assistance to private industrial enterprises; however, it was opened for business in August 1962 (CBOS, 2nd Annual Report, 1962, p. 41).

In June 1963, Credit Lyonnais was renamed to El-Neileen Bank due to the Sudan's government contribution in its capital (CBOS, 5th Annual Report, 1964, p. 58).

In 1967, the Real Estate Bank of Sudan was established (CBOS, 8th Annual Report, 1967, p. 58) to provide the financing to the housing sector specially the citizens of low incomes (Osman, 1992, p. 53).

By the end of February 1969 Turkish Ottoman Bank was renamed to National Grindleys Bank 
(Omer, 1992, p. 52).

In 1970, the Sudanese government nationalized all the commercial banks under the Nationalization Act, therefore, five banks were nationalized and renamed as follows:

-Barclays'Bank was renamed State Bank of Foreign Trade.

- Arab Bank Limited was renamed Red Sea Commercial Bank

-Ethiopian Bank was renamed Juba Commercial Bank

- National and Grindleys Bank was renamed Omdurman Bank.

- Misr Bank was renamed People’s Cooperative Bank

By the end of the 1960s, the structure of the banking system consisted of the Central Bank (Bank of Sudan), as well as seven commercial banks: Sudanese Commercial Bank in 1960, El-Nilien Bank in 1964, Omdurman National Bank 1970, which was established after the nationalization of National \& Grindleys Bank, Bank for Foreign Trade in 1970, Juba Commercial Bank in 1970. The Red Sea Commercial Bank in 1970, Popular Commercial Bank in 1970. In addition to the three specialized banks to serve the development objectives, namely: The Agricultural Bank of Sudan in 1958, the Industrial Bank of Sudan in 1961 and the Real Estate Bank of Sudan in 1967. The total number of banks was eleven including the Bank of Sudan. The nationalization decision and confiscation of foreign banks branches later affected the Sudanese banking system. This led to weakening the confidence of foreign investors, shareholders and depositors, especially in the period after 1970.

During the period 1965-1970, the branches of the Bank of Sudan reached eleven and were distributed through the various states of Sudan including the capital, Khartoum (CBOS, 11th Annual report, 1970, pp. 94-99).

It is very clear from the discussion above that most commercial banks were foreign banks with the exception of Sudanese Commercial Bank and El-Nilien Bank, which classified as national commercial banks through the period up until 1970. Besides, some specialized finance companies and social guarantee institutions had been established.

\subsection{The Second Phase (1971-1977)}

The Nationalization Act in 1970 had led to negative implications for the country's economy in general, and the banking sector in particular. The number of branches of the Central Bank of Sudan decreased from eleven to nine, closing both Bahr El-Ghazal and Upper Nile State branches. In 1973, the Savings and Investment Council was established to encourage savings and investment in line with the banking system.

As a result of the nationalization decisions in 1970, the number of state-owned banks increased and another was merged while some foreign banks were established. Red Sea Commercial Bank was merged which El-Nilien Bank and Juba Commercial Bank was incorporated with National Bank of Omdurman under new name Juba-Omdurman Bank. Further in 1973, State Bank for Foreign Trade was renamed to Bank of Khartoum and 
Juba-Omdurman Bank was renamed The Unity Bank in 1975 (Awatif Yousef, 1997).

At the end of 1974 the Sudanese Saving Bank was established as a state-owned bank. It was inaugurated at Wad-Medani City as a pilot scheme. It was established for the purposes of, encouraging and gathering savings, developing saving awareness in general and directing attention towards small savers in particular. To that end it was investing these savings in productive as well as service sectors which were in need of funds and associated with small producers (Omer, 1992, p. 53).

Moreover, Sudan Development Corporation (SDC) was established in 1974, as a national development institution to assist in the promotion and acceleration of the socioeconomic development of the Sudan through financial and managerial assistance to the existing and new projects that are economically sound, technically feasible and financially viable (Annual Report of the Board of Directors, 1997, p. 1).

In 1975 The Nationalization Act 1970 was amended and became the Banking and Savings Regulation Act 1975. Based on the new regulations, five existent commercial banks had been registered as private companies in which the Bank of Sudan owned shares in return for compensation paid to the old owners (Bank of Sudan, 16th Annual Report, 1975, pp. 76-77).

The authorities had decided to adapt the so-called "Open Door Policy" (ODP) in 1976. The international community was invited to invest in Sudan under the slogan of "Sudan Bread Basket of the World" Program. Therefore, a new investment Act was decreed in 1976. According to that, Faisal Islamic Bank was established in 1978 as the first Islamic bank in Sudan, which followed by many foreign commercial banks. These are The Arab African Bank, the Chase Manhattan Bank, the Bank of Credit and International Trade, National Bank of Abu Dhabi, the First National City Bank, Habbib Bank, Oman Bank, Middle East Bank, and Bank for Credit and International Commerce (Omer, 1992, p. 55).

The period (1971-1975) witnessed the deterioration of the banking sector in Sudan due to implementation of the Nationalization laws. The Investment Act was issued in 1976 in order to encourage and give guarantees to foreign investors from nationalization and confiscation. Therefore, Abu Dhabi National Bank established in 1976 as a foreign bank, Bank of Credit \& International Commerce established in 1976, General Organization for Financing \& Cooperative Development established in 1977 to grant short- long term finance to cooperatives, Citi Bank in 1977 got licensed to operate in Sudan (Bank of Sudan, 18th Annual Report, 1977, p. 53).

\subsection{The Third Phase (1978-1982)}

In the field of Islamic commercial banks, Faisal Islamic Bank (Sudan) was established mid-1978 as a limited shareholding company with a capital of 6 million pounds of which 40\% was paid by Saudi Arabia, $40 \%$ by Sudanese shareholders and $20 \%$ by other Islamic and Arab Countries. The bank started its operations according to Shari'a Law or Islamic system (Bank of Sudan, 19th Annual Report, 1978, p. 57). Later in 1979, the bank opened four branches in Omdurman City, Port-Sudan City, University of Khartoum and Omdurman Islamic University. 
In 1980, four joint banks were granted initial licenses to operate in Sudan, two of them traditional commercial banks; El-Wadi Bank and National Bank of Sudan, as well as, two Islamic banks including Al-Jazeera Islamic Bank and Islamic Bank of West Sudan. In addition, three foreign banks were licensed to operate in Sudan including Islamic Bank for Finance and Investment, Habib Bank and American Bank or Bank of America.

During the last quarter of 1980, Bank of Oman began to provide banking services (Bank of Sudan, 21nd Annual Report, 1980, p. 80). In 1981 Tadamon Islamic Bank granted primary license to operate its Islamic banking services (Bank of Sudan, 22nd Annual Report, 1981, p. 70).

In 1982 there were three new banks operating in Sudan including: National Bank of Sudan as a joint bank, Middle East Bank as foreign bank branch, Popular Development Bank as integration bank between Egypt and Sudan (Bank of Sudan, 23nd Annual Report, 1982, p. 82). As a result of $O D P$, the banking system network covered wide areas of the country that stimulating banking competition. Therefore, Popular Cooperative Bank was merged with Bank of Khartoum in 1982.

\subsection{The Fourth Phase (1983-1989)}

In September 1983, government announced that Shari'a Law (philosophy of Islamic system) should be applied in the banking system. Therefore, riba (interest rate) was totally forbidden in Sudanese banking system. In the same year, there were five banks licensed to practice Islamic banking in Sudan. Tadamon Islamic Bank was established in 1983, Sudanese Islamic Bank, Islamic Cooperative Development Bank, National Bank for Export and Import and Blue Nile Bank. Also both of Al-Gharb Islamic Bank and Al-Baraka Bank (Sudan) ratified a final license to work by the start of 1984 (Bank of Sudan, 24th Annual Report, 1983, p. 81).

After Sudan introduced Shari'a Law (Islamic Law) in 1984, the banking and financial industry changed its practices to conform with Shari'a. Hence, commercial banks were obliged to conform to Shari'a Law and avoided riba (usury) or interest rate in their banking transactions (Bank of Sudan, 25th Annual Report, 1984, p. 76).

The first period of the Islamization of the banking system in Sudan (1984-1989), witnessed flexibility in implementation of Islamic modes and in 1986, banks were allowed to operate either with Islamic modes of financing or with an interest rate. This situation was continued until the Central Bank of Sudan announced that a deepening Islamization of the banking system, would be applied in 1990.

In 1986, Saudi-Sudanese Bank was established, so the number of banks in the country increased to 22 (Sudan of Bank, 27th Annual Report, 1986, p. 58). In 1987, final licenses were issued to Worker's Bank to start its operations in 1988, National Bank of Omdurman plans to operate in 1988, therefore, number of banks increased to 23 (Bank of Sudan, 28th Annual Report, 1987, p. 63). In June 1989, the Philosophy of Islamic Banking was generalized to all the Sudanese banking system.

On the other hand, during the period (1984-1989), the number of foreign bank branches 
remained at six. This can be attributed to an ending of the policy of establishing new foreign branches in Sudan. Also the total number of both public sector banks and specialized banks remained at four. But the classification of joint banks (Islamic joint and non-Islamic joint) was cancelled and became known as joint banks.

\subsection{The Fifth Phase (1990-1994)}

The deepening Islamization of the banking system (interest rate becoming completely forbidden in the Sudanese banking system) started in 1990 alongside the establishment of Alshamal Islamic Bank. Furthermore, the Banking Regulation Act was issued in 1991 followed by the Economic Liberalization Policies in 1992 (CBOS, 1992 Annual Report, p. 59).

On March $2^{\text {nd }} 1992$, the government established the High Shari'a Supervisory Board on Islamic Financial Institutions (HSSBIFIs) to ensure the compatibility of banking and financial practices with Islamic principles. In compliance with the HSSBIFIs, the government is no longer selling treasury bills and government bonds; instead, the Bank sells "Financial Certificates" that comply with Islamic financial principles.

In 1992 some commercial and specialized banks, owned by the government, were merged in accordance with the liberalization policies in order to raise their capital adequacy and meet international solvency standards. National Bank for Export and Import, The Unity Bank and Bank of Khartoum were merged with the Bank of Khartoum.

Also El-Nilien Bank and Industrial Development Bank of Sudan were merged into one bank renamed El-Nilien Bank Group for Industrial Development. Post \& Telegraph Savings Fund was incorporated into Savings Bank. So, in 1992, the number of specialized banks decreased to three banks whereas, the number of public sector banks declined to two banks including: Bank of Khartoum Group and El-Nilien Bank Group for Industrial Development (Bank of Sudan, 32th Annual Report, 1992, pp. 41-43). Also in 1992, Farmer's Bank for Rural Development and Sudanese-French Bank were opened (Omer, 1992, pp. 55-56).

In 1993, Animal Resources Bank and Omdurman National Bank were established while the Middle-East Bank was liquidated. By the end of 1993 the number of the commercial banks and specialized banks operating in country reached 28 (Bank of Sudan, 33th Annual Report, 1993, pp. 36-37).

In 1994 the Bank of Sudan announced that Reconstruction Program and the Reform of the Banking System (RPRBS) started and it ended in July 1997. The RPRBS aimed to restructure the banks in order to build and create a strong banking system which has financial solvency and which makes it qualified to face global competition in the banking industry. Within this program, CBOS adopted the Basel Committee on Banking Supervision (BCBS) standard. Consequently, the Bank formed a committee in July 1994 which continued functioning up to the end of 1998. It was then transformed into a unit in the preventive control section in the Banking Control Department. The unit has been entrusted with the duty of the following up, study, analysis and the evaluation of the affairs of banks with regard to the restructuring requirements. It then reported quarterly, biannually and annually. The said unit revised the 
bases of restructuring with a view to incorporate the BCBS measures into the Islamic banking system in the Sudan. In this context, the unit formulated risk weight standards for some Islamic banking transactions which have no similar practices in the traditional banking system. It has also formulated a system by which finance and bad debts were appropriated and re-evaluating fixed assets with regard to capital expenditure (CBOS, 38th Annual report 1998, p. 42).

In general, during the period 1990-1994 the branches of foreign banks were reduced while Credit and International Trade Bank was closed in 1991. In 1992, Bank of Oman was renamed to El-Mashreq Bank. Also Middle-East Bank was liquidated and therefore, the number of foreign banks was only four by the end of 1994. Islamic Bank of West Sudan was also renamed to Algarab Islamic Bank and National Bank for Popular Development renamed Nima Bank for Investment \& Development (Bank of Sudan, 34th Annual Report, 1994, pp. 42-68).

\section{Reform Stages (1995-2005)}

In 1995, Ivory Bank was established and Khartoum Stock Exchange Act was ratified and started its activities at the beginning of 1995. By the end of the same year, the license for the establishment of new commercial banks was suspended but allowed for investment banks. Hence the number of operated banks in Sudan reached twenty-nine banks (Bank of Sudan, 35th Annual Report, 1995, pp. 38-53). In 1996, El-Gadarif Bank for Investment was opened. As for RPRBS the Bank of Sudan classified the working banks into four groups as follows:

- The First Group: Banks that have improved their situation by $100 \%$.

- The Second Group: Banks have adapted some of their positions but need more effort. The committee advised this group through of the following points: Capitalization on their profits, increase of their capital, liquidation some of their fixed assets and shares investments.

- The Third Group: Banks need a great effort to reform their positions. The committee advised this group through of the following points: Capitalization their profits, increase of their capital, liquidation some of their fixed assets and shares investments, reduce expenses and increase revenues.

- The Fourth Group: Banks that did not provide the required data and information.

Based on the situation of banks from the reform project until 31st December 1996, there were a number of banks that had made an effort to adjust their situation. On the other hand, there were some banks in need of a great effort to adjust their situation. As for the specialized banks of the public sector, Savings Bank was renamed to Savings and Social Development Bank in 1995. Deposits Guarantee Fund Act was approved by the National Transitional Council in 1996. The law aimed to increase the confidence of savers and depositors in the banking system. It started its operations in 1997 (Bank of Sudan, 37th Annual Report, 1997, pp. 45-50).

In the context of banking supervision, Bank of Sudan in 1998 continued to implement the 
$B C B S$ Accords to enhance banks' ability to fulfill the financial solvency and to cope with global competition. In frame of reform the position of the banks, banks according to capital adequacy ratio are classified into five groups:

- Banks achieved capital adequacy ratio more than 15\%: Well capitalized (5 Banks).

- Banks achieved capital adequacy ratio 8\%-15\%: Adequately capitalized (9 Banks).

- Banks achieved capital adequacy ratio 4\%-8\%: Undercapitalized (5 Banks).

- Banks achieved capital adequacy ratio 2\%-4\%: Significantly undercapitalized (2 Banks).

- Banks achieved capital adequacy ratio less than $2 \%$ : Critically undercapitalized (3 Banks).

The Department of Banking Supervision started in 1999 to revise the basis of reforms of the banks' positions in order to make them consistent with the specific nature of Islamic banks. In this area the Central Bank of Sudan advised the commercial banks to follows the following procedures:

- Accumulate a new provision for bad debts taken in their account of the nature of Islamic banks.

- Banks should use a new risk weighted average for partnership certificate of the Central Bank of Sudan (Shamam), partnership certificate of the Government (Shahama) and according to the nature of those certificates, the risk weight is equal to zero (CBOS, 39th Annual report, 1999).

With regard to RPRBS, Citi Bank was liquidated voluntarily in 1998. In mid-1999, Sudanese Commercial Bank and Farmer's Bank for Investment were merged and renamed Farmer's Commercial Bank. Following that, Financial Investment Bank was established and both of Nima Bank for Development and Investment and Al-Safa Bank were compulsory liquidated in 1999 (Bank of Sudan, 40th Annual Report, 2000, pp. 18-33).

In May 2000, RPRBS re-issued and it was aimed to increase the capital of all banks by the end of 2002 to SDD three billion. In 2001, Bank of Sudan in cooperation with International Monetary Fund (IMF) began to implement of prudential banking supervision by using new performance criteria (Bank of Sudan, 41 th Annual Report, 2001, p. 12).

In light of RPRBS by the end of the year 2002 four of private sector banks was increased their capital to SDD two billion and twelve of them was increased their capital to SDD one billion while one bank could not fulfil the restructuring requirements.

On the other hand, Bank of Khartoum was turned into a public liability company and Real Estate Bank was sold to the private sector. Meanwhile, steps are underway to convert El-Nilien Bank into a public liability company. However, the Agricultural Bank remained for the purpose of financing agricultural sector while Savings \& Social Development Bank was remained to alleviate poverty (Bank of Sudan, 42nd Forty-second Annual, 2002, pp. 24-25). Consequently, the total number of commercial banks reached twenty-one banks by the end of December 2002 (Abid, p. 52). 
The Banking System Organization Act of 1991 was amended by the Act of 2003 to cope with local and international banking changes. In the area of banking supervision, the basic conditions required to establish banks were revised, and the regulations organizing the activities of finance companies were issued.

In the year 2003, RPRBS was planned to increase of capital reserves of banks from SDD 73692 million to SDD 110308 million. In the same context there were five banks in the private sector which fulfilled the minimum requirements by raising their capital to SDD three billion, nine banks to SDD two billion, three banks to SDD one billion, two others chose the option to merge, while one failed to meet the requirements of the first stage of the program (Sudan of Bank, 43th Annual Report, 2003, p. 63).

Concerning the public sector banks, the Bank of Khartoum, El-Nilien Bank for Industrial Development and Savings and Social Development Bank all completed the final stage of RPRBS by increasing their capital to SDD three billion while Agricultural Bank is in the process of increasing its capital. As for public sector banks, El-Nilein Bank was under preparation for privatization. As for foreign bank branches, two of them were given a grace period to raise their paid up capital from USD 10 million to USD 12 million, while the third started work in the year 2003 with a capital of US\$12 million (Ibid, pp. 24-25).

During the period (2001-2003), branches of the specialized banks in public sector decreased to 142,133 and 124 branches in 2001, 2002 and 2003 respectively. As for the public sector, commercial banks decreased their branches to 113 in 2001 but increased from 138 branches in 2002 to 172 branches in 2003. On the other hand, joint banks (commercial and specialized), decreased their branches to 323, 259, 228 branches in 2001, 2002, 2003 respectively due to the requirements of RRPBS (Ibid, p. 152).

CBOS in 2004 continued in the implementation of RPRBS, where most of the banks succeeded in raising their paid-up capital to the minimum requirements of SDD 3 billion. Based on that, the total number of banks reached twenty-six banks, of which were twenty-three commercial banks and three were specialized banks distributed across the different states. Although some banks were closed and others opened, the total bank's branches were 526 of which 34\% were in Khartoum State (Bank of Sudan, 44th Forty-fourth Annual Report, 2004, pp. 11-57).

The year 2005 witnessed the signature of Comprehensive Peace Agreement (CPA) between North and South Sudan in Kenya after over two decades of protracted war. A referendum enshrined in this agreement led to a separation between North Sudan and South Sudan in July 2011 and the consequent birth of South Sudan as the newest state. As at the beginning of 2005, there were only four banks in operation in South Sudan (Atem, 2018, p. 85).

Furthermore, the implementation of Item 14 of the Protocol of the Division of Wealth between North Sudan and South Sudan under (CPA), confirmed the commitment to the basic principles of unity of: The Central Bank of Sudan, the Monetary Authority, monetary policy, the currency and the role of the Central Bank of Sudan in economic stability. The organizational structure of Bank of Southern Sudan was set up where training of some 
employees from north has been achieved. Also, the work plan of the departments of bank through the peace phase was prepared beside procedures for issuing the new currency and the reorganization of the structure of the Central Bank of Sudan continued during 2005. Thus, under Item 14 of CPA, there were two different banking systems; Islamic in North Sudan and conventional in South Sudan (CBOS, 45th Annual Report, 2005, p. 30).

After CPA, there are several banks in North Sudan that fulfilled the requirements of RRPBS. This program presented wide options to banks, represented in the three following stages:

\section{- The First Stage: Evaluation of Banks' Situations through Approved Auditing:}

The competent entities for evaluating the banks according to the conditions and criteria set by The Central Bank of Sudan for the selection of these entities were announced. Consequently, an agreement was reached with these entities regarding the bases and requirements for the financial evaluation of the banks. Net value and the value of banks' stocks were determined in stock exchange. In this stage, the banks had the option of forming of groups as a step towards the merging operations, alongside the determination of the group leaders according to the conditions stipulated by the Central Bank of Sudan.

\section{- The Second Stage: Formation of Alliances among Banks:}

Implementation of this stage basically depended upon the results of the financial evaluation of banks in the first stage in the light of which of the group's alliances and group leaders were determined.

\section{- The Third Stage: The Merger Among the Allied Groups:}

This phase was considered actual stage of merger among the allied banks under the supervision of the Central Bank of Sudan. In this stage, banks benefitted from the incentives that accompanied the merger operation. The bases and legalities pertaining to the merger were completed during this stage (Ibid, p. 29).

In 2005, Alsalam Bank and Sudanese Egyptian Bank were established and joined the commercial banks in North Sudan, so, the total number of operating banks increased but their branches were reduced from 526 to 517 .

\section{CPA and Banking System (2006-2010):}

In August 2006, according to compliance with the banking aspect of the (CPA), a comprehensive, organizational and administrative restructuring of the CBOS was carried out with the aim of bringing together similar functions under the umbrella of specialization in order to strengthen co-ordination among them.

A system of strategic planning for the CBOS was adopted to determine the macro objectives and work towards realizing them via stages of annual transitional and flexible plans and programs which will enable the monitoring and introduction of the required changes in ease. Moreover, the method of strategic plans assists in securing harmony and complementarity of the inter-sectoral plans in addition to securing the required finance for their programs for attaining the specified goals and objectives (CBOS, 2005, The 5-year strategic Plan). 
As for banking activity in South Sudan, the CBOS continued to implement item (14) of the CPA Protocol and it completed the preparation for adopting a dual banking system, establishing the Bank of Southern Sudan (BOSS), issuing the unified new currency and formulation of the rules and regulations which govern the establishment of conventional banks in the South. In accordance with that, two banks, namely Kenyan Commercial Bank and the Nile Commercial Bank were licensed to operate in the South. A number of the employees in the different departments of CBOS in north were dispatched to train the employees in the (BOSS). Moreover, a number of the employees of BOSS were trained in the Bank's headquarters in Khartoum.

In order to achieving the unity of the currency, the Sudanese pound (symbol SDG) was adopted instead of the Sudanese dinar (symbol SDD) to be used in the North and South of Sudan according to the text of the CPA; it was in circulation at the beginning of 2007.The replacement of currency was continued up until June 2007 at which point the pound became the only legal tender currency (CBOS, 46th Annual Report, 2006, p. 30).

In the year 2007, under the RPRBS, a number of banks succeeded in fulfilling the specified requirements. Concerning the strengthening and reinforcing of the financial positions of the banks, 95\% of them were able to increase their capital to SDG 40 million. With regard to strengthening and reinforcing the financial positions of the banks, 95\% of them were able to increase their capital to SDG 40 million. Also the first stage began through the division of banks into six groups, giving them the opportunity to move from one group to another; also government ownership in the banking sector was reduced through privatization (CBOS, 47th Annual Report, 2007, p. 29).

During 2007, the number of banks operating in North Sudan totaled thirty-two banks whose branches spread throughout the different States while Nile Bank and Kenya Commercial Bank joined the system of banks operating in South Sudan, consequently, the branches of the CBOS remained at twelve, as in the year 2006 (Ibid, p. 43).

In year 2008, the number of banks operating in Sudan totaled thirty-five banks, therefore, Aljazeera Bank, Qatar National Bank and Family Bank joined the system of banks operating in north Sudan while Buffalo Bank in the South (CBOS, 48th Annual Report, 2008, p. 35).

The branches' number of the CBOS remained unchanged (14 branches) in 2009. Whereas the number of banks operating in Sudan reached thirty-eight banks. Arab Sudanese Bank joined the system of banks in north Sudan while both Commercial Bank of Ethiopia and Equity Bank were joined to banks in the South of Sudan (CBOS, 49th Annual Report, 2009, p. 45). In the year 2010, in the context of banking activities in South Sudan, the number of bank branches operating under the dual system (Islamic and conventional) reached (34) as shown in Table1.

Table 1. Banks operating in South Sudan in 2010

\begin{tabular}{ll}
\hline Bank Name & No. of Branches \\
\hline Agricultural Bank of Sudan & 4 \\
\hline
\end{tabular}




\begin{tabular}{ll}
\hline Buffalo Bank & 3 \\
Commercial Bank of Ethiopia & 1 \\
El-Jebal Bank for Trade and Development & 1 \\
Equity Bank & 1 \\
Ivory Bank & 7 \\
Kenya Commercial Bank & 5 \\
Nile Commercial Bank & 12 \\
\hline
\end{tabular}

Source: Central Bank of Sudan (South Branch).

As seen in Table1:

- The number of banks operating in South Sudan (all of them conventional except the Agricultural Bank of Sudan which operated under two systems (Islamic and conventional)).

- The number of conventional banks' branches totaled thirty branches, represented in seven banks namely; Nile Commercial Bank, Kenya Commercial Bank, Ivory Bank, Equity Bank, Buffalo Bank, Commercial Bank of Ethiopia and El-Jebal Bank for Trade and Development which joined the system of banks in 2010 (CBOS, 50 ${ }^{\text {th }}$ Annual Report, 2010, p.81).

\section{Structure of Banking System in Sudan (2011-2019)}

After secession of South Sudan in July 2011, the number of banks operating in North Sudan reached thirty-three in 2011; compared to thirty-nine in 2010. As result of the secession, local currency in northern Sudan was totally replaced by new currency in September 2011 (CBOS, 51st Annual Report, 2011, p.62).

By the end of 2012, the Central Bank of Sudan increased its branches from ten to fifteen branches which were distributed across different states of Sudan. Five new branches were opened in the following cities: El-jeninna, Eldamazin, Sennar, Kadogoly and Kassala. On the other hand, the total number of the commercial banks reached thirty-five banks where National Bank of Egypt and Abu Dhabi Islamic Bank was joined the system of banks in North Sudan as foreign banks (CBOS, 52th Annual Report, 2012, pp. 49-51).

In 2013, the Central Bank of Sudan (CBOS) continued its RPRBS, where thirty-three banks completed their capital requirements (SDG 100 million) and constituted $89 \%$ of the total banks. In this context, the CBOS issued a set of regulations to lay foundations for effective corporate governance and internal control systems (CBOS, 53th Annual Report, 2013, p. 34).

The CBOS continues to delegate more responsibilities and empowers its branches to undertake their advisory and supervisory roles so as to become mini-central banks in the respective states. This is planned to be done through completing the opening of CBOS branches in all states. The branches of CBOS reached 16 by the end of 2013 when Zalingi branch was inaugurated. Moreover, the CBOS policies for the year 2013 aimed to enhance the role of his branches in spreading banking and economic awareness as well as enlightening 
customers with the available banking services. On the other hand, the total number of banks reached thirty-seven banks, where the year 2013 witnessed the entry of two new banks to the banking sector in Sudan including Qatar Islamic Bank and Elrowad Bank for Development and Investment (Ibid, pp. 37-58).

In the year 2014, the CBOS policies were aimed at applying the Guiding Principles of Islamic Shari'a (GPIS) to all financial transactions which related to the banking system through the implementation of Islamic modes of finance. Moreover, activating and developing the HSSBIFIs as well as the other Shari'a supervisory boards and Shari'a auditors in the banks. HSSBIFIs helped in promoting the Islamic Banking System as a perfect substitute of the conventional system and continued to promote it regionally and internationally. Accordingly, CBOS branches were increased to seventeen branches by the end of 2014, where Deayn branch was inaugurated recently while the total number of banks remained at thirty-seven banks (CBOS, 54th Annual Report, 2014, pp. 32-33).

The CBOS policies for the year 2015 under the banking supervision axis were aimed at achieving the following: enhancing the banks' compliance with the international standards issued by BCBS and Islamic Financial Services Board (IFSB) as well as the Financial Soundness Indicators (FSIs), through improving banks' financial efficiency, tightening banking supervision and addressing the weaknesses of banks to safeguard the depositors' rights and ensure optimal allocation of resources through activating the role of the boards of directors and empowering the internal audit and monitoring units and compliance officers.

In this regard, the CBOS exerted robust efforts to improve the performance of the capital adequacy, corporate governance and risk management indicators under the unfavorable economic conditions experienced by the country. To this end, the CBOS policies aimed to reach $(6 \%)$ that represents the international standard limit regarding non-performing loans (NPLs), in addition to enhancing the overall position of banking indicators to improve the banks' ability to compete domestically and internationally (CBOS, 55th Annual Report, 2015, p. 31).

In the area of deepening and developing the Islamization of the banking sector, CBOS continued to activate the role of HSSBIFIs and Shari'ah Supervisory Boards of the banks by applying the Islamic Shari'ah guidelines relating to the interbank market and developing new compliant Islamic modes of finance to assist in managing the monetary and microfinance policies. Besides that, the cooperation between the CBOS, Sudanese Banks Union and HSSBIFIs, continued to encourage the development of new modes of finance to meet the customer needs that are not satisfied by the current modes.

The HSSBIFIs continued to develop and document Islamic banking and the financial experience of Sudan, through focusing on electronic publishing by developing and updating a website (www.hssb.gov.sd), which facilitates the easy viewing of Fatawa (issues treated by HSSBIFIs, besides the sub-private link the HSSB, on the Central Bank of Sudan website. On the other hand, the total number of banks operating in Sudan remained at thirty-seven banks, as it was in 2014 (Ibid, pp. 34-35). 


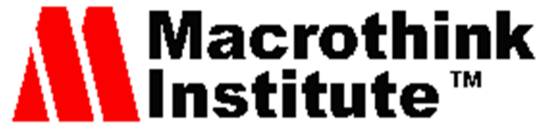

The CBOS policies for 2016 in axis of Islamic Banking aimed to deepen Islamization, through activating the role of HSSBIFIs and the Shari'ah Supervisory boards in banks, through the implementation of Islamic Shari'ah guidelines relating to the interbank market, developing new Islamic compliant finance contracts to assist in monetary policy and microfinance management.

The Cooperation between the CBOS, Sudanese Banks Union and (HSSBIFIs), has continued in order to develop new financing contracts to meet the customer needs that were not satisfied by the current contracts. As for the Fatawas, the HSSBIFIs issued a fatwa concerning the financing of health services and another one concerning Murabaha (Purchase Order) between Abu Dhabi National Bank and the Directorate of Strategic Stock Reserve in order to improve banking sector employees' and clients' capacity regarding Shari'ah aspects - particularly Fiqh Mu'amlat (Islamic Commercial Law) and in cooperation with the relevant authorities. In addition, a number of training courses and lectures were organized with respect to Fiqh Mu'amlat of financial and banking transactions, Shari'a rulings on sales and issues in the practice and risk associated with the Islamic financing contracts in various Sudanese states. With regards to fostering Sudan's external relations with Islamic institutions, (HSSBIFIs) hosted the public hearing session on the drafting of gold standards prepared by the Accounting and Auditing Organization of the Islamic Financial Institutions (CBOS, 56th Annual Report, 2016, p. 31).

The CBOS implements its policies through its seventeen branches, as it was at the end of 2015 and distributed across the various states of Sudan. The total number of banks in Sudan remained at thirty-seven in 2016 as it was 2015 (Ibid, p. 47).

During the year 2017, HSSBIFIs issued four fatwas' and one decision regarding:

- Commission of conduct of Murabaha (Purchase Order).

- Financing travel agencies to purchase tickets.

- The decision of dealing between individuals and companies which have joint ownership by Murabaha (Purchase Order).

By the end of 2017, the total number of banks operating in North Sudan remained at thirty-seven banks as it was in 2016 while branches of CBOS remained at seventeen branches as in the year 2016 (CBOS, 57th Annual Report, 2017, pp. 44-47).

Table 2 and Figure 1 summarize the number of banks operating in North Sudan after the period of separation up to the year 2019 while Figure 2 shows the structure of the Islamic banking system by the end of 2019 .

Table 2. Number of Operating Banks in North Sudan (2011-2019)

\begin{tabular}{llllllllll}
\hline Item & $\mathbf{2 0 1 1}$ & $\mathbf{2 0 1 2}$ & $\mathbf{2 0 1 3}$ & $\mathbf{2 0 1 4}$ & $\mathbf{2 0 1 5}$ & $\mathbf{2 0 1 6}$ & $\mathbf{2 0 1 7}$ & $\mathbf{2 0 1 8}$ & $\mathbf{2 0 1 9}$ \\
\hline Branches of CBOS & 10 & 15 & 16 & 17 & 17 & 17 & 17 & 17 & 17 \\
(1) Specialized Banks & 5 & 5 & 5 & 5 & 6 & 5 & 5 & 5 & 5 \\
- Joint* & 2 & 2 & 2 & 2 & 3 & 1 & 1 & 1 & 1 \\
\hline
\end{tabular}


- Government 2021, Vol. 8, No. 1

(2) Commercial Banks

3

$3 \quad 3 \quad 3$

344

\begin{tabular}{ll}
4 & 4 \\
32 & 32 \\
24 & 24 \\
1 & 1 \\
7 & 7 \\
$\mathbf{3 7}$ & $\mathbf{3 7}$ \\
\hline
\end{tabular}

Source: CBOS-Annual Reports (2011-2019).

* The Joint Banks are the Banks in which the local sectors (Governmental or Private) and the foreign sector contributed in their capital.

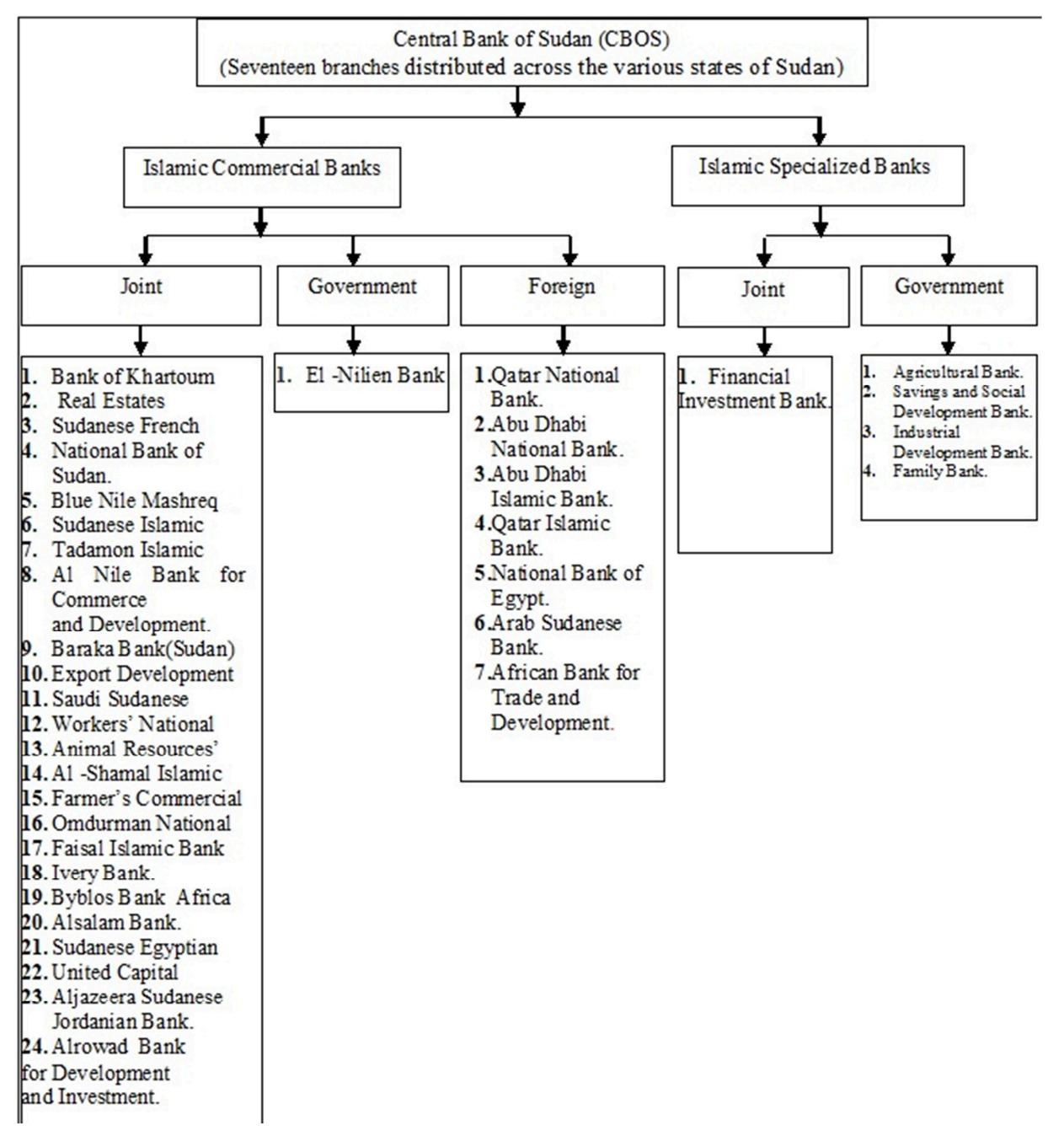

Figure 1. Map of Islamic banking system-North Sudan (2019)

As seen in Table 2 and Figure 1.

- The total number of branches of the CBOS reached ten, fifteen, and sixteen branches in 2011, 2012, and 2013 respectively, while the number of branches remained at seventeen over (2014-2019). It was distributed across the various states of Sudan. 
- The total number of Islamic banks (specialized and commercial) reached thirty-three banks in 2011 including five specialized banks and twenty-eight commercial banks.

- The total number of banks (specialized and commercial) reached thirty-five banks in 2012 including five specialized banks and thirty commercial banks.

- The total number of banks (specialized and commercial) reached thirty-seven banks in 2013 where two new banks entered the banking sector in Sudan including Qatar Islamic Bank and Elrowad Bank for Development and Investment.

- The total number of the banks (specialized and commercial) remained at thirty-seven banks in 2014; also the number of the specialized banks remained at five.

- The total number of the banks (specialized and commercial) remained at thirty-seven banks in 2015 as it was in 2014, while the number of the specialized banks increased from five banks in 2014 to six banks in 2015, as a result of classifying Alrowad Bank for Development and Investment as a joint specialized bank, and reclassifying Ivory Bank as commercial foreign bank instead of a commercial joint bank.

- The total number of the banks(specialized and commercial) remained at thirty-seven banks in 2016 as it was in 2015, where the number of the specialized banks decreased from six banks in 2015 to five banks in 2016, while the commercial banks increased from thirty-one banks in 2015 to thirty-two banks in 2016 as a result of reclassifying of Alrowad Bank for Development and Investment from a specialized bank to a commercial bank, while the number of commercial foreign banks decreased from eight banks in 2015 to seven banks in 2016 due to reclassifying Ivory Bank as commercial joint bank instead of a commercial foreign bank (CBOS, 56th Annual Report, 2016, p. 50).

- The total number of banks operating in Sudan in 2017 remained at thirty-seven banks, as it was in 2016 (Central Bank of Sudan, 57th Annual Report, 2017, p. 47).

- Similarly, to the year 2017, there are no changes in the structure of the banking system for the years 2018-2019 (CBOS, 59th Annual Report, 2019, p. 53).

Generally, the structure of the Islamic Banking System in Sudan by the end of 2019 was categorized as follow:

- The Central Bank of Sudan: main branch located in Khartoum with seventeen branches distributed across the various states of Sudan.

- Thirty-two Islamic commercial banks including twenty-four joint banks, one government bank, and seven branches of foreign banks.

- Five Islamic specialized banks including four government banks and one joint bank.

Now all the banks (specialized and commercial are operating under the Guiding Principles of Islamic Shari'a (GPIS) through implementation of Islamic modes of financing which includes: Mudarabah (passive partnership), Shirkah or Musharakah (active partnership), Murabahah (cost plus service charge), Ijarah (leasing), Ijarah wa iqtina' (hire-purchase), Salam (forward 
delivery contract), Istisna (contractual production) and Qard Hassana or good loan with zero interest rate (Mustafa, 2019, p. 16).

\section{Conclusions}

- Politically, the emergence of commercial banks in Sudan can be attributed to the joint British and Egyptian rule in 1903.

- Although the origin of Islamic banking can be traced back to the birth of Islam in the 14th century, the first experience of establishing an Islamic bank emerged in Egypt in the early 1960s, so historically Sudan considers from the early Islamic Countries that implemented the Principles of Islamic Shari'a in its banking operations in the opening of Faisal Islamic Bank (Sudan) in 1978.

- The reviewing of stages of development of Islamic banking in Sudan showed that there is a fluctuation in the philosophy of its management as it began to rely on the conventional legacy of banking until 1982.

- The implementation of the Islamic sharia law in 1983 was the first basis for the deepening of the Islamization of the banking system in Sudan, particularly the prohibition of dealing with the interest.

- Under the Comprehensive Peace Agreement (CPA: 2005-2010), conventional banking (the interest rate) in South Sudan was returned and with a continuation of the Islamic approach in the north but all banks were managed by one central bank in the north is called Central Bank of Sudan.

- The date July 2011 is an important year in the history of Sudan where the South seceded the North. Banking activities in the north of Sudan became managed by the Central Bank of Sudan under the principles of Islamic Shari'a. The Bank of South Sudan was established and became an independent central bank responsible for conventional banking in the south.

- Political instability is considered the fundamental factor that played an important role in the formation and division in the stages of developing the Islamic banking system in Sudan during the period 1903-2019.

- The Central Bank of Sudan was exerted great efforts in reforming the banking system through implementing the Reconstruction Program and the Reform of the Banking System (RPRBS) to enhance banks' ability to fulfill the financial solvency to cope with global competition.

\section{Recommendations}

- There is a need to pay attention to factors that lead to political stability to ensure the stability of the banking system.

- The Central Bank of Sudan should continue to fulfill international standards to strengthen the structure of the banking system.

- Sudan has experience in banking for more than 115 years; thus, the study recommends the 
importance of documenting and publishing this experience to benefit from it locally, regionally, and globally.

\section{References}

Abrahim, A., \& Abdelgadir, M. (2011). Efficiency of Islamic Banks in Sudan: A non-parametric Approach. Journal of Islamic Economics, Banking and Finance, 7(4), 79-92. https://doi.org/10.1108/17538391111122186

Alharbi, A. (2015). Development of the Islamic Banking System. Journal of Islamic Banking and Finance, 3(1), 12-25. https://doi.org/10.15640/jibf.v3n1a2

Alshosh, T. E. (1997). Legal Position of Banking System and Bank of Sudan. Bureau of Economic Research.

Atem, G. G. (2018). Bank of South Sudan's Governance, Nature, Growth and Impact of Banking Sector on the Economy. Journal of Economics and Finance, 9(1), 82-95. https://doi.org/10.9790/5933-0901018295

Bank of Sudan. (2019). History of Banking in Sudan. Retrieved May 20, 2019, from https://en.wikipedia.org/wiki/Central_Bank_of_Sudan

Bank of Sudan. (n.d.). Various Annual Reports, Khartoum, 1979-1989.

Bank of Sudan Act. (1959). Section 5.

CBOS. (2005). The 5 Year Strategic Plan. Retrieved May 20, 2019, from https://cbos.gov.sd/en/content/5-year-strategic-plan

CBOS, Central Bank of Sudan. (2019). About Central Bank of Sudan, Research and Studies Series. $\quad$ Retrieved May 20, 2019, from https://cbos.gov.sd/en/about-cbos/about-central-bank-sudan

CBOS, Central Bank of Sudan. (n.d.). Various Annual Reports (2001-2017). Retrieved from http://www.cbos.gov.sd

El-Khalil, A. (1999). Specialized Banks and its Role in Development.

Magda, I. (2005). The Practice of Islamic Banking System in Sudan. Journal of Economic Cooperation, 26(4), 27-50.

Mekasha, G. (2011). Credit Risk Management and Its Impact on Performance on Ethiopian commercial Banks. Published Master Thesis, Addis Ababa University. Retrieved from http://etd.aau.edu.et/handle/123456789/3643.

Mohamed, U. (1990). Islamic Banking in Sudan's Rural Sector. This paper was presented in the Seminar on "Financial Institutions Working in accordance with Shari'ah" which was sponsored jointly by IRTI- IDB and the Government of the Republic of Indonesia held in Jakarta, 17th-19th August, 1990. Retrieved July 29, 2019, from https://www.irti.org>Research>IES 


\section{Macrothink}

Mohamed, Y., Awatif, E. M., \& AbdElmoneim, M. M. M. (1997). The Role of the Bank of Sudan in Management of Banking System (1960-1997). High Institute for Banking \& Financial Studied.

Mohammad, T., Mohd, Y., Mohd, A., \& Ummu, Z. (2013). The Historical Development of Modern Islamic Banking: A study in South-east Asia countries. African Journal of Business $\begin{array}{lllll}\text { Management. } & \text { Retrieved } & \text { July } & 2019, & \text { from }\end{array}$ https://umexpert.um.edu.my/file/publication/00008863_98913.pdf

Mumtaz, H., Asghar, S., \& Rima, T. (2015). An Overview of Islamic Finance. IMF Working Paper, WP/15/120. June 2015. African, European, and Middle East and Central Asia Departments. https://doi.org/10.5089/9781513590745.001

Mustafa, O. A. O. (2019). Assessment of the Financial Performance of Islamic Commercial Banks in Sudan under Credit Risk and Inflation Pressures (1995-2017). Journal of Islamic Banking and Finance, 7(1), 14-26. https://doi.org/10.15640/jibf.v7n1a2

Omar, T. A. S. (1992). The Banking System Development in Sudan. Paper presented at a symposium on "Sustainable Rural Development" 06/ Farmers Bank for Investment and Rural Development, Khartoum, 1992.

Osman, H. S. (1992). The Industrial Bank of Sudan 1962-1968: An Experiment in Development Banking. Khartoum.

Shahid, E. (2011). Islamic banking in Sudan. SSRN Electronic Journal. https://doi.org/10.2139/ssrn.1926895

Sudan Development Corporation. (1997). Annual Report of the Board of Directors for the year 1997.

\section{Notes}

Note 1. The experts were:

- Mr: Oliver Weale, Vice chairman of the Federal Reserve Bank of Francisco as president.

- Mr: Alan R. holmes from the Federal Reserve Bank of New York as a member.

- Mr: Andrew F. Primer from the Federal Reserve Bank of New York as a member.

\section{Copyrights}

Copyright for this article is retained by the author(s), with first publication rights granted to the journal.

This is an open-access article distributed under the terms and conditions of the Creative Commons Attribution license (http://creativecommons.org/licenses/by/4.0/). 